3) Riggs, D. S. et al. : J. Biol. chem.,143:363. 1942.

4) Bruger, M.\& Member,S. : J. Biol.chem., $143: 77.1943$.

5) Taurog, A.\& Claikoff.I.L. : J. Biol.chem., $171: 439,1947$.

6) Rall,J.A. : J. clin.Endocrinol., 10:966, 1950.

7) Taurog, A.et al. J. Biol.chem.,180: 99, 1950.

8) Rosenberg, I.N. : J.clin.Invest., 0:1, 1951.

9) Robbinson. J. etal.: J. clin.Endocrinol.,12: 856, 1952.

10) Gross, T.J. \& Pitt-Rivers,R. : Lancet, 1 : 439, 1952.

11) Danowski, T.S. et al. : J. clin.Endocrinol., $10: 519,1950$.
12) Man, E.B. et al.: J.clin.Invest.,30:531,1951.

13) Benua, R.S. \& Dobyns, B.M.: J. clin. Endocrinol., $15: 118,1955$.

14) Robinson,J. : J. Biol, chem., $208: 377,1954$.

15) Plummer, H.S.: J. Am. Med. Assoc.,77: 243, 1921.

16) Taurog. A. \& Chaikoff,I.L. : J.Biol.chem , $176: 639,1948$.

17) Means, J.H. \& Lerman,J. : J. Am. Med. Assoc., $104:$ 969, 1935.

18) Lerman, J. \& Means,J.H. : Am. J. Med, Sci., $181:$ 745, 1931.

19) Lund, G.et al. : Biochem. Zeitschr., 206 : $261,1928$.

20) Benua, R.S. \& Dobyns, B.M. : J. clin. Endocrinol., 12:856, :952.

\title{
沃度代謝に関する臨床的研究
}

第 3 報 血清非キロキシン性有機沃度 $\left(\mathrm{N}^{\prime} \mathrm{TX}\right)$ について $\begin{array}{ccc}\text { 中 } & \text { 野 } & \text { 和 } \\ \text { 群馬大学医学部第 } 1 \text { 内科教室（主任 } & \text { 七条小次郎 教授） }\end{array}$

緒 言

第 2 報に記載した如く健康人及び各種用状腺 疾患患者の NTX は非常に僅少であり，人及び 小動物に $I^{131}$ を投与し一定時間後の血清のベー パークロマトグラフのラヂオオートグラフに於 てすらNTXは証明されていない(Laidlow 等1) Taurog 等(2) Roseuberg 等 ${ }^{3)}$ Gross等()) NTX の構成沃化物として最も考号られ易い物質は Diiodotyrosine と Monoiodotyrosine である が, これ等の物質は翈状腺, 肝, 腎等の組織で 速かに脱沃度される為に，たとえ甲状腺で Thyroxineより多量に形成されたとしても末 稍血流中には殆んど証明されないわけである (Roche等5) Tong等6) 中野等 ${ }^{7}$ ).

しかし既に述心た如く（第 2 疑）無機沃度， 乾燥甲状腺末等の然機有機沃度剤の投与を受け
た患者の血清 NTXは或時期に著明に増加して いた。しかしこの物質が如何なる有機沃化物で あるかについては全く記載されていない.著者 は現在行い得る最良の方法を用いて，NTX を 追究した。なお各章に於て破究の進め方が違う 為一定の形式で記述する具を避け，各場合に臨 んで実験う法，成纈灭びその検討を一括して記 述したいと舁う。

\section{Lugol 療法時の NTX}

1） NTX は n-Butanol 可溶性物質か否か? 30日間 Lugol 氏液の投与を受けた健康者 3 名の血清について次のう法で実験して見た。こ れ等の血清 Thyroxine 及び PBIは表 1 に示す 如くである. 先ず血清 $2 \mathrm{cc}$.を $1 \mathrm{~N} \mathrm{H}_{2} \mathrm{SO}_{4}$ で $\mathrm{pH} 3.0$ とし 2 倍量の n-Butanol で 3 回抽出，各抽出 液は合せて減圧蒸溜器に移し， $\mathrm{N}_{2}$ ガスを通じつ 


\begin{tabular}{|c|c|c|c|c|c|c|c|c|c|}
\hline \multirow[b]{2}{*}{$\begin{array}{l}\text { Sect } \\
\text { No. }\end{array}$} & \multirow[b]{2}{*}{ 添加沃化物の位置 } & \multicolumn{2}{|c|}{ Exp. 1} & \multicolumn{2}{|c|}{ Exp. 2} & \multicolumn{2}{|c|}{ Exp. 3} & \multicolumn{2}{|c|}{ Exp. $4^{*}$} \\
\hline & & $\begin{array}{c}\mathrm{PBI} \\
\mathrm{TX} \\
\mathrm{NTX}\end{array}$ & $\begin{array}{l}8.3 \gamma / \mathrm{dl} \\
5.2 " 1 \\
3.1 "\end{array}$ & $\begin{array}{l}\mathrm{PBI} \\
\mathrm{TX} \\
\mathrm{NTX}\end{array}$ & $\begin{array}{l}9.6 r / \mathrm{d} 1 \\
7.0 \mathrm{\prime \prime} \\
2.6 \mathrm{\prime \prime}\end{array}$ & $\begin{array}{l}\text { P B I } \\
\text { TXX } \\
N T X \\
\end{array}$ & $\begin{array}{c}11.3 \gamma / \mathrm{dl} \\
5.8 \mathrm{\prime \prime} \\
5.5 \mathrm{\prime}\end{array}$ & $\begin{array}{c}\text { P B I } \\
\text { TX } \\
\text { NTX }\end{array}$ & $\begin{array}{l}5.4 r / d 1 \\
5.2 " ~ \\
0.2 "\end{array}$ \\
\hline 1 & Thyroxine & & $.144 \gamma$ & & $.116 r$ & & $.085 \gamma$ & & $0.092 \gamma$ \\
\hline 2 & Diiodo-tyrosine & & 0.016 & & 0.018 & & .017 & & 0.013 \\
\hline 3 & Monoiodo-tyrosine & & 0.010 & & 0.017 & & .008 & & 0.010 \\
\hline 4 & & & 0.014 & & 0.013 & & .013 & & 0.010 \\
\hline 5 & Morg. iodide & & 0.700 & & 2.041 & & .159 & & 0.031 \\
\hline 6 & Origin & & 0.010 & & 0.012 & & .008 & & 0.012 \\
\hline
\end{tabular}

* Lugol 未治療健康人

つ減压下に $45^{\circ} \mathrm{C}$ で $0.1 \mathrm{cc}$. に港縮した。ペーパ 一クロマトグラフイの前に, 著者の方法 で得 た $I^{127}$ 既知の $I^{131}$ labeled-Thyroxine, Diiodotyrosine, Monoiodotyrosine及び Carrierfree I 131 を上記湦縮液に mark として加えた後, そ の一定量を濾紙に塗布し, 醋酸ーブタノールー水 $(15: 100: 37)$ を溶媒として一次元法で展開し た. 添加沃化物のペーパークロマトグラム上の 位置を知る為に，これ等の滤紙はラヂオオート グラフイの為にX線 フイルムに 3 日間密着さ せ，現象した。その後これ等の滤紙は一定の間 隔で 6 分し, 紙片に切られ, 著者の方法でその 中に含まれる沃度量を測定した。ここに得られ た值から添加沃化物の沃度量及び滤紙の盲験值 を減じた值を求めんとする沃度量とした。表 1 は実験值を示したもので，沃度剂の投与を受け た例（Exp.1から 3 まで）では，無機沃度は沃 化物中最も高萃を示し, 総沃度に対するそれの 百分涪はそれぞれ 78.7，90.5 及び $83 \%$ であつ た。

未投与の場合 (Exp.4) と比較する目的で沃 度を除外した総沃度量に対する各沃化物の百分 率を表示して見ると図 1 の如くで血清の各沃度 分割は沃度郕の投与の有然に関係なく䀩问樣な 割合を示した。既に著者等8)が発表した如く， 血清に添加した I ${ }^{131}$ labeled-Diiodotyrosine 及 び Monoiodotyrosineは Somogyi 氏除蛋白法

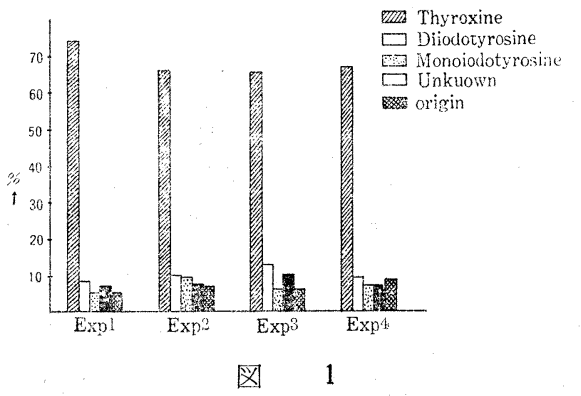

で PBI と其に各々59，69\%が沈澱するが，血清 をpH3.0として n-B̉utanol で抽出した場合こ れ等沃度化チロヂンの $90 \%$ n-Butanol 中に 移行する. 從つて血清 $\mathrm{TX}$ の半量又はれ以上の 值を示す NTX を Diiodo 及び Monoiodotyrosine と仮定した場合，その血清の $\mathrm{n}$-Butanol抽 出液をクロマトグラフィにより分析したDiiodo 及び Monoiodotyrosine の総和は Thyroxine と同率か又はそれを上まわつてよいわけであ る.しかしここに得られた結果はその仮説を否 定せざるを得なかつた。

全くDiiodo 及び Monoiodotyrosine の存在 を認められていない健康人血清において，それ 等が10\%内外の割合で測定される事は, 求めん とする沃度量が微量な為誤差を生じ易い事とり ロマトグラフイで各沃化物が全く完全に分離さ れ難いという事に基づいて説明し得る。

\section{2） NTX は沃怼化蛋白算か否加?}

n-Butauol 不溶性の 血清 蛋白質分劃を $2 \mathrm{~N}$ 
$\mathrm{NaOH}$ 又は Trypsine で水解後ペーパークロマ トグラフイにより沃化物の定量を試みたが，ア ミノ酸が多量な為に武料の展開が不完全な事と 求めんとする沃度化合物の沃度量が微量な為に 測定不能に終つた。そこで次の方法を用いて， 血清中に比較的高濃度にイオン沃度が存在する 場合血清蛋白質の沃度化が起るか不かを観察し た。

無菌的に分離した健康人血清 $0.5 \mathrm{cc}$. を 2 本の 小試験管にとり，その各々に $I^{127}$ として 0.25\%, $\mathrm{I}^{131}$ として $5 \mu \mathrm{c}$ の沃度を含む Krebs-Ringerphosphate-buffer (pH7.4) 0.5cc. 加え, 一 方に蒸溜水 $0.1 \mathrm{cc}$. 他方に $30 \% \mathrm{H}_{2} \mathrm{O}_{2}$ 0.1cc. 加え てょく混和後, 两者を $37.5^{\circ} \mathrm{C} 90$ 分間好気的に反 応させた。 反応終了後 $I_{2}$ の電位を低下させる 目的で稀アルカリを加えて $\mathrm{pH} 8.0$ 以上とし，そ

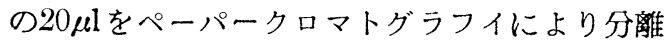
し, 型の如くラヂオオートグラフィを行つた。 各々の滤紙は $1 \mathrm{~cm}$ 間隔でガイガーミユーラー カウンターでカウントした。図 2 に示す如く $\mathrm{H}_{2} \mathrm{O}_{2}$ 非添加時は無機沃度が総沃度の 約 $90 \%$ を 占め, クロマトグラムの原点即ち沃度化蛋白質 の部分には約 $0.2 \%$ を占めるに過ぎなかつた。 一方 $\mathrm{H}_{2} \mathrm{O}_{2}$ 添加時では全く逆でクロマトグラム の原点が総沃度の約 $90 \%$ 上めていた（図 $3 \mathrm{a}$ ) この原点の部分の滤紙を切り取り $0.02 \mathrm{~N} \mathrm{NaOH}$

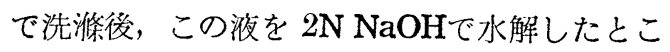
ろ図3b に示す如く多量の Monoiodotyrosine 少量の Diiodotyrosine 及び Thyroxine を認め た.この結果血清は $\mathrm{H}_{2} \mathrm{O}_{2}$ 添加時においてのみ その蛋白質が沃度化される事を知つた。文外気 を遮断し無菌的に採取した血清に上記 $\mathrm{I}^{127}$ I $\mathrm{I}^{131}$ 沃度液走加光 $37.5^{\circ} \mathrm{C} 5$ 日䦎反応させたが沃度化 蛋白質の形成を認める事が出来なかつた。

3） NTXはn-Butanol で完全に抽出されず Somogyi 氏除蛋白液で沈激する沃化物 か否か?

蛋白質を 分子沃度で 沃度化する場合，その Tyrosine 残基が完全に沃度化された場合には, odohistidine ${ }^{9,10)}$ 及び IodotryptophanI") の形

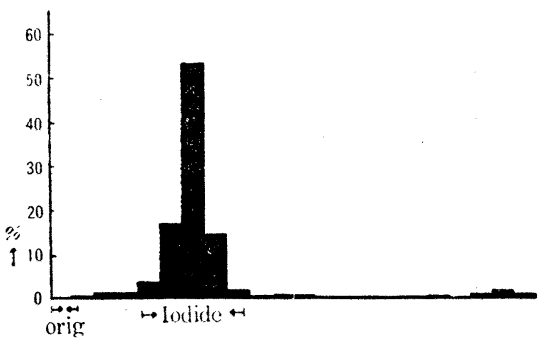

図 2

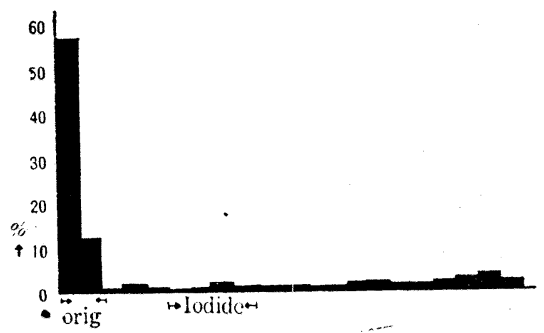

区 3 a

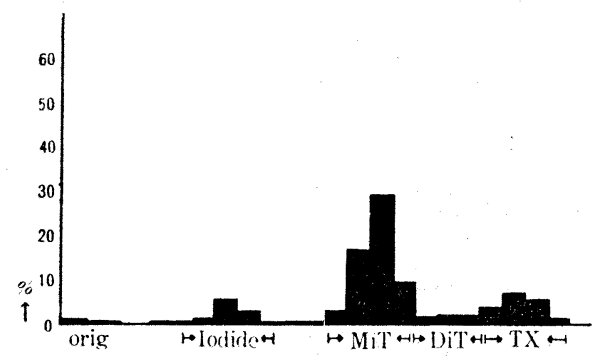

园 3 b

成が考えられている。特に Iodohistidine は Roche等 ${ }^{12,13)}$ により正常白鼠の甲状腺及び血清 中に証明されている。又既に発表した如く血清 に添加した 2 Monoiodohistidine は $\mathrm{pH} 3.0$ で n-Butanolによりその30\%が抽出されるに過ぎ ず, Somogyi 氏除蛋曰液によりその半量以上 が沈澱する事から，最も考えられ易い物質であ

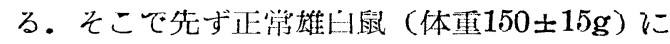
沃度力リ（1匹1日量50r）を20日間投与し，蒋 物投与を中止した後 Carrier-free I ${ }^{131}$ の: $00 \mu \mathrm{c}$ を皮下注射した。24時間後放血致死させ，白率 甲状腺を Trypsine て 3 日間水解し ${ }^{14}$, その水 解液に合成 2Monoiodohistidine, 2-5Diiodohistidine を加元醋酸ーブタノールー水 (15:100:37) 又はヂオキサンーブタノールー $2 \mathrm{~N} \mathrm{NH}_{4} \mathrm{OH}$ 
(1:4:2)を展開溶楷としてペーパークロマトグ ラム及びそのラヂオオートグラムを作成した。 一兮この滤紙は Diazo化 Sulfanilicacidで督簿 した。この操作で Monoiodohistidine は橙色 Diicdohistidine は璌色に発色した。（図 4 a， 4b）ラジオオートグラフ上には無機沃度 Mono 及び Diiodotyrosine, Thyroxine の他に, ヂ オキサンによるクロマトグラム」に水解操作 1:の分解物之推定される不明化合物及び $3: 5$ diiodo-4hydroxyphenylpyruvicacid が琹めら れたが, Monoido 及びbiiodohistidine に怢当 する黒化带は認められなかつた。

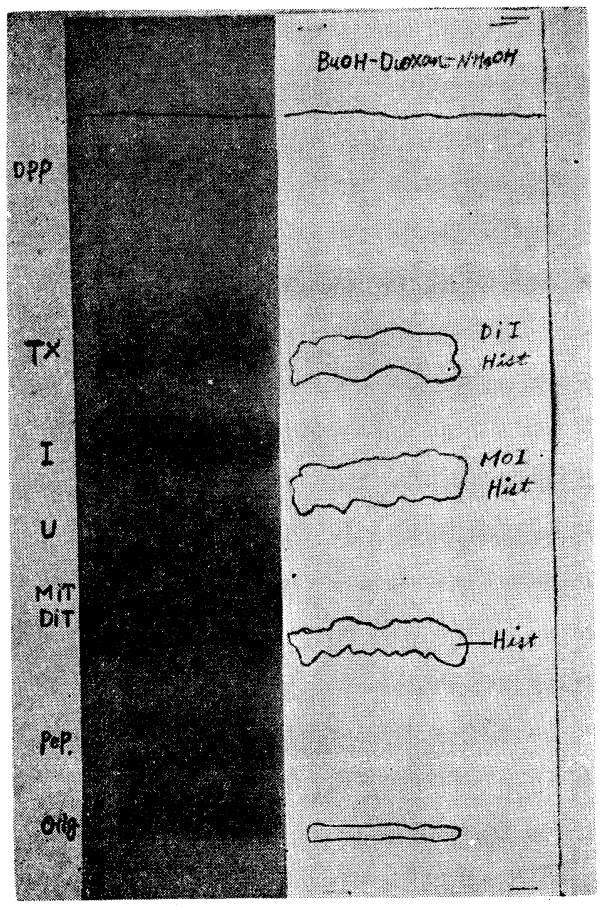

四4a ペーパークロマトグラム（右）と そのラヂオオートグラム（左）

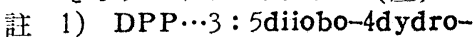
$x y p h e n y l y r u u i c a c i d$

2) TX...Thyroxine

3) I...lodide

4) U...不明化合物

5) MIT...Monoiodotyrosine

6) DIT...Diiodotyrosine

7) PeP...Peptide

8) DITHist $\cdots$ Diiodohistidine

9) MOTHist...Monoiodolustidine

10) Hist...Histidine

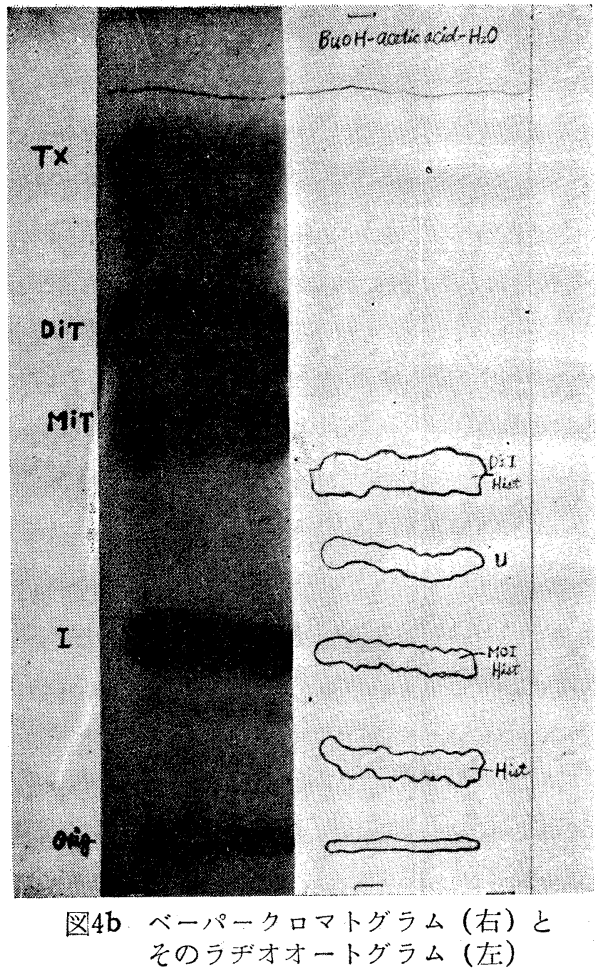

\section{II 乾燥甲狀腺末}

乾燥甲状腺末の投与後短時間の血消に見られ る NTX の垍加は嘅に第 2 報に述べたところで あるが，之の NTX の組成を究明する為炏の実 験を行つた。休重 $200 \pm 13 \mathrm{~g}$ の雄白鼠に $0.02 \mathrm{~N}$ $\mathrm{NaOH}-0.9 \% \mathrm{NaCl}$ に溶解した $\mathrm{I}^{131}$ labeled thyroid（ $\mathrm{I}^{131}$ 投与後 24 時間の白瓦甲状腺で $\mathrm{I}^{131}$ として $50 \mu \mathrm{c} ， \mathrm{I}^{127}$ として $1.5 \gamma$ を含む，を経口投 与し， $1 / 2$ 時間から 8 時間迄の一定間隔で血清の 放射能及びそのペーパークロマトグラフイによ り条沃化物の放射量を測定した。一方投与甲状 腺中の Thyroxine, Monoiodotyrosine 及び Diiodotyrosine の量 ( $\mathrm{I}^{127}$ 及び $\mathrm{I}^{131}$ ) は者者の方 法で測定し得るから，これにより投与忖状腺中 各沃度化合物に対する血清沃化物の割合が算さ れる. 図5に図示する如く， I ${ }^{131}$ labeled thyroid 投与後30分では殆んど認められなかつた血中の 放射量は 2 時間後に至り急に増加し，この時期 には Diiodotyrosine 及び Monoiodotyrosine が割合に多く認められたが，時間の経過と共に 速かに消失した。 之に反し Thyroxine は次第 に増加した。その他 2 時間後のラヂオオート 


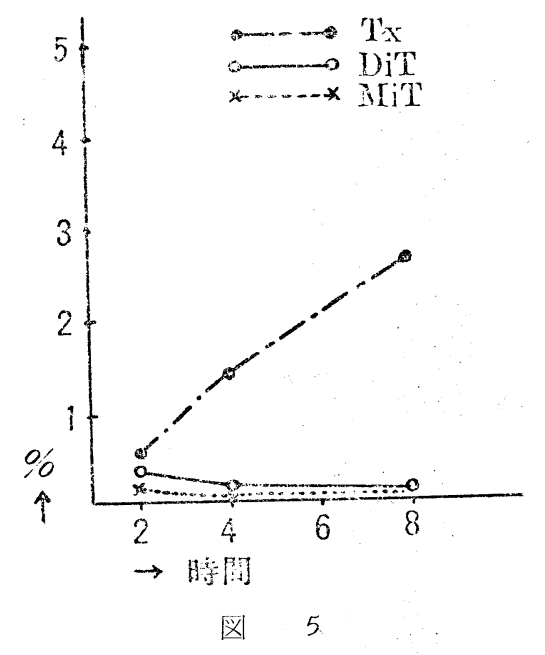

グラフはには沃度化ペプチツド Diiodo 及び

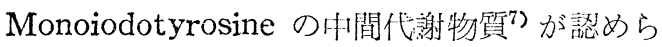
れた。彷つて人に用状腺末を投与した後 1 ～ 2 時閪後に見られる NTX の増加は Somogyi 氏 除蛋白湤でその半量以亡が沛搌するMonoiodo 及び Diiodotyrosine と若えられる。

\section{考察}

Lugol 氏液の投与を受けた健康人，甲状腺 機能元進炡及び 低下祉患者の血清に見られる NTX の增加は，単に血清蛋白質と共に沈測す る無機沃度でなく，Diiodotyrosine の様な物質 と推定されている $\left(\right.$ Man 等 $\left.{ }^{15}{ }^{16}\right)$ ) 一方 Salter 等17)は血清に多量のイオン沃度を添加し約 5 日 間反応させた場合 PIIT が軽度に増加する 可か ら NTX を沃度化量白質と考えている。

しかしここに得られた者者の成續から Lugol 氏被投与後見られるNTX の増加は，血清中 に逝離状態で存在する Monoiodotyrosine, Diiodotyrosine 及び Iodohistidine，又は沃度 化蛋白質とも考元難く，恐らく血中の沃度量が 或一定漕度に到達した時に血清蛋白質に吸着 された沃度によるものと推祭された。 Lugol一 Methiocil の拃用投与を受けた用状腺機能九進 症思者のI伤でも又NTX が增加した(前記).こ こで Methiocil が生体内で沃度化サイオウラシ ルの様な物質に変化したと仅定しても，この物 質は Somogyi 氏除整白液で PBI として沈澱 し, しかもn-B̈ntanol で抽出後 J́lau 氏塭で洗 桬しても除去されない為 (Peters等 ${ }^{18)}$ ) NTXは
治療前值と治療中の值と全く変らないわけであ るが著者の成績は全くこれに反していた。そこ でこの場合の NTX も恐らくLugol 単独投与時 のそれと同様な物質であらう。健䐂者に甲状腺 末を投与した後短時間に見られるNTXの增加 は，Somogyi氏除蛋白法で半量以上を沈搌する Monoiodo 又は Diiodotyrosine と考えられる。

\section{結語}

1）Lugol 氏淮の表期間投与後，又は乾燥甲 状腺末の投与後見られる血清 NTX の増加を来 す顷質を程々なう法を用いて研究した。

2）Lugol 氏液の投与後見られるNTX の增 J埕血清中に遊離状態で存在する Monoiodotyrosine, Diiodotyrosine 及び Iodohistidine, 沃废化㔻印㟓とは考光難い。

3) 稪燥川状腺未投与後短時間に見られる NTXはMonoiodotyrosine及びDiiodotyrosine と若えられる。

沃度代謝に関する臨床的研究を行うに際し, 終始御 鞭㩲を賜つた七条小次郎, 百瀬勉(九大薬学)雨教授, 研究の御便宜を戴いた野口秋人博士（野口病院長）怔 びに野口病院甲状豚研究所杉維子薬学土, 洼田美津子 君に謝意を表す。

\section{文献}

1) Laidlaw,J.C. : Natur, $164: 927,1949$.

2) Taurog.A.et al. : J.Biol.chem., 180:99, 1950.

3) Rosenberg,I.N.: J . clin. Inves.,30:1, 1951.

4) Gross,J.\&Leblond,C.P.: Science, III 605,1950.

5) Roche, J. et al.:Bioclem.et Biophys. Acta, $9: 161,1952$.

6) Tong,W.et al : J . Biol.chem., $207: 59,1954$.

7) 中野稔, 杉利子: 内分泌, $3(3): 236$,

$$
\text { " " : 生体科学, 8(2): 83, }
$$

8）田中茂, 中野稔: 最も新しいホモルン検查法: 甲 状腺ホルモン, 175頁 昭31年

9) Brings,K.J.: J. Am. chem.Soc.,69:205, 1947.

10) Li, C.H. : J .Am.chem. Soc., $66: 225,1944$.

11）赤堀四郎等: 蛋白質化学第 II 巻（編集水舅三一郎 等) 31 頁

12) Roche, J .et al.: Biochem.et Biophys.Acta, $8: 339,1952$.

13) Roche. J. et al.:Compt.rend., 232:2047,1951.

14) 中野稔: 生体の科学, 7(6): 315 ,

15) Man,E.B.et al. : J.clin.Inviest.,21 : 273,1942.

16) Man, E.B.et al.: J.clin.Inviest.,30:531,1951.

17) Salter,W.et al: Jclin.Endocynoll.,8:911,1948.

18) Peters, J.P. \& Man,E.B. : The Thyroid (editor Werner.S.C.) $137 \mathrm{p}, 1955$. 